\title{
A Brief Discussion on Amelioration and Revolution in Late Qing Dynasty in Horizon of Political Modernization
}

\author{
Xu Linping, Guo Xiu
}

Dehong Teachers’ College, Mangshi, Yunnan, 678400

Keywords: political modernization; amelioration in the late Qing Dynasty, the Revolution of 1911

\begin{abstract}
At the end of the Qing Dynasty, China was facing such double impacts as foreign enemy invasion and ruling order reform of feudalism. The failure of the Sino-Japanese War of 1894-1895 has made Chinese modern history enter into a vital turning period. The thesis, in the horizon of political modernization, has studied the amelioration and the revolution in the late Qing Dynasty, with the main research thinking that by basing on the Chinese social crisis outbreak at the end of the Qing Dynasty, the Chinese modernization amelioration and revolution has been discussed, and at the same time, amelioration and revolution in the late Qing Dynasty have been differentiated and analyzed in the horizon of political modernization.
\end{abstract}

\section{Introduction}

After the First Opium War, imperialist powers invasion and the domestic turmoil impacted on the traditional feudal ruling class. And the then feudal government, in order to maintain dynastic ruling, raised the westernization drive. However, the failure of the Sino-Japanese War of 1894-1895 has made Chinese modern history enter a vital turning stage. Political reforms and amelioration in the late Qing Dynasty play an important role in the historical process of Chinese modernization, so choosing in the horizon of political modernization, to analyze amelioration and revolution in the late Qing Dynasty can reflect the sequence of thought of political modernization development in that period, having great significance on deeply understanding Chinese modern thoughts and events.

\section{Crisis in Late Qing Dynasty and Formation of Chinese Political Modernization}

After the Sino-Japanese War of 1894-1895, China met the tide of carving up lands, and various unequal treaties of the western powers made the then China disintegrate. For example, Treaty of Shimonoseki with Japan, Sino-Russian Secret Treaty with Russia, and Jiao and Ao Concession Agreement with Germany, etc., let western powers control Chinese finance and taxation in a treaty signing manner, making the Chinese national crisis extremely unparalleled and serious.

When western powers were carving up China, the Qing government, in order to maintain its ruling, levied taxes on farm lands from people, making ordinary people more live on the edge of starvation, so some of them pacing up and down between the life and the death can only rush into danger to oppose. During that time, various small and big civil commotions occurred. In the Civil Commotion Chronology of Late Qing Dynasty, there are totally more than 1300 civil commotions everywhere, indicating that the national continuous civil commotions have erupted overall.

The late tax period is the most serious one in every dynasty's feudal rule stages, and according to relevant records, tax items in the late Qing Dynasty were at least 60[1]. After the western powers' carving up China, during more than 10 years in the late Qing Dynasty, foreign merchants robbed the owner while his house is on fire by hoarding for speculation plenty of rice and flour, etc., leading to such civil commotions' occurring as grabbing rice, grain boats and flour factories, etc. The most typical one is the burning grand coordinator government offices, foreign firms and churches in 1910 in Changsha of Hunan Province, reflecting irreconcilable conflicts among various interest groups in the late Qing Dynasty, which have very strong function on the political modernization's occurring.

Before the Sino-Japanese War of 1894-1895, the then Qing Dynasty's Beiyang navy's power was regarded as the best in Asia, while the war result shocked all people in the world, which is closely 
related to the then Qing government's backward system and corruption[2]. The westernization drive initiated by the Qing Dynasty though promoted the social productivity development and the early capitalism growth, explored the modernization by focusing on utensils, such as new guns, warships in military industry, while armed forces were still the the Qing ones of a feudal military system, so if feudal troops with advanced weapons fight against new Japanese troops, the fighting result can be understood without saying.

Before the Sino-Japanese War of 1894-1895, the Qing westernization drive developing for 30 years had not make the Dynasty get rid of the strong feudal character, while the westernization drive development thoroughly disappeared after the Sino-Japanese War of 1894-1895, which reflects the late Qing government's great limitation of only initiating the modernization of utensils.

After the Sino-Japanese War of 1894-1895, the government abolished the maladministration, and merchants rescue the nation with industry and commerce, so a situation good for developing capitalist industry and commerce has been formed. Although weak, the emerging national bourgeoisie are new productivity declaring publicly new direction for social development. Besides, Western learning transmission and Western book translation promoted the idea of science and democracy needed by modernization, and with the science and democracy reforming continuously the productivity as well as the relation of production, the society changed. New-style schools and capitalism joining the society changed Chinese students' thinking, and students studying in some other place or abroad tended to be diverse in knowledge structures and value orientations, also taught in Chinese new-style schools after graduation with cultivating a large batch of intellectuals of new thinking, which all have positive function on Chinese political modernization's occurring.

\section{Dual Variations of China's Political Reform and Revolution under Political Modernization}

After the Sino-Japanese War of 1894-1895, in Chinese society stimulated by the defeat and humiliation, the social crisis became prominent, and Reform Movement of 1898 led by Kang Youwei and Liang Qichao just could respond to such a crisis [3]. When signing the Treaty of Shimonoseki was known by Kang Youwei going hither and thither to call for proposing submitting a written statement to the higher authority by all successful candidates in the imperial examinations at the provincial level in the Ming and Qing dynasties to make clear that only reform movements can make China safe and sound as well as achieve self-improvement, a national influence has been produced and that Reform Movement of 1898 of reforming for innovation occurred. That Reform Movement of 1898 based on maintaining the emperor authority, requests feudal scholar bureaucrat to promote the system reform from the senior to the junior, however, due to involving "ancestor rules", that Reform Movement of 1898 faced sharp and fierce contradictions.At the same time, in that Emperor Guangxu was not the highest governing authority, that Reform Movement of 1898 only lasted for 100 days. Although is a failure, Reform Movement of 1898 has laid a vital theory basis for Chinese process of modernization.

On January 29, 1901, the Empress Cixi sent out imperial decree to assume the blame during escaping to the western China, which reflects the beginning of the new deal in the Qing Dynasty. In bureaucratic establishment, the new deal cut down superfluous government offices and officials, also stopped buying official posts, as well as abolished the objectionable practices; in military establishment, Luying troops, Yongying troops and Fanglian troops, etc. were cut down to set "Xinjun Troops", also schools of defense preparations were established; in the educational system, eight-part essays were abolished to set up discourse on politics, also some students were selected to learn abroad, with the studying in some other place or abroad rewarded; in industry and commerce, laws were set up and industry and commerce were rewarded. Those new measures had some effects, but still cannot make the China get rid of feudal autocracy, making people suspect the New Deal.

The Russo-Japanese War (1904-1905) is a war of Political Constitutionalism. The Qing Dynasty government under pressures from various part, felt itself cannot govern continuously as before, so declared the "provisional constitution making" to look for a way out, however, due to unprepared regulations and people's not understanding, that Constitutionalism has not been carried out.

The Qing government has delayed and wasted several reform chances one by one, having a true 
intention to write a play and to direct a hoax of maintaining its governing, with its true intention finally showing the cloven foot [4]. The Qing government's political amelioration has proved: that a government fooling the history and people must be thoroughly abandoned by the history and people.

In November, 1905, Sun Yat-sen has proposed the Three People's Principles in a foreword to People's Periodical, namely initiating "Nationalism, Democracy, the People's Livelihood”, which is Sun Yat-sen's experience and lessons summarized from modernization processes of European and American countries, also the only way which must be passed by rescuing China and realizing prosperous and strong China thought by Sun Yat-sen. A political guiding principle of Chinese society development formed by the United League of China led by Sun Yat-sen, has made clear that the Three People's Principles contained ideas and plans of national independence, democracy and happiness of the people's livelihood. Although roads for achieving those objectives have not been found later, that Three People's Principles have encouraged billions of Chinese people to struggle for them.

Tung Meng Hui, a Bourgeois Democratic Republic and an interim senate initiated by Sun Yat-sen are all representatives of Chinese bourgeois democracy, vital measures of democratic republic revolution reforms.

Political amelioration and bourgeois revolutions of the Chinese government in late Qing Dynasty have made the Qing government disintegrate directly, with the revolution forms and constitutionalists’ practice accelerating the Qing Dynasty’s falling apart.

\section{Discriminating Amelioration and Revolution in Late Qing Dynasty in Horizon of Political Modernization}

Reform movement of 1898 though not as successful as Meiji reform, has laid a solid foundation for the succeeding of the Revolution of 1911, also has provided solid guarantees for China's stepping on a modernization road [5]. With the rise and development of modern Chinese capitalism, the new urban bourgeoisie and the rural gentry class have formed to cause political instability and turmoil. Establishing a unified nation needs a powerful central government and political authority as a repression, while establishing political authority needs to solve problems of regime legitimacy and governance effectiveness.

Regime legitimacy was the main crisis faced by the late Qing Dynasty, so such political reformers as Kang Youwei failed due to some traditional groups feeling their status threatened and opposing. After the failure of reformers' measures, the traditional authority lacking validity still governed China, while in order to avoid conflicts, the subsequent bourgeois revolutionaries adopted with constitutionalists a way to compromise and cooperate, laying hidden troubles for the following the Republic of China's development.

Obtaining and consolidating a legal regime highlights the ruling effectiveness. Reformers looking for political amelioration though described a beautiful blueprint for the emperor, carried out the political amelioration by depending on the Emperor Guangxu of less real power, so that reform only lasted for 100 days with tiny effects. Also people's life had no change after that. People were still in difficulties. It can be predicted that if that reform had succeeded, the national political crisis would have been difficult to solve. Because after the Sino-Japanese War of 1894-1895, Chinese international prestige has been lower and lower, with the political power effectiveness lacking, so in the long term, what the reform supported is a power lacking effectiveness, which will hardly ensure the power's legality. Traditional society instability plus the political decline will make the bottleneck of social change broken, and the hoax of the Qing Dynasty's feudal ruling will also be unmasked.

The political participation expansion is often regarded as the measure of the level of national political modernization. People's joining politics mainly includes supervising the government administration, expressing opinions and organizing joining and so on [6]. The political participation expansion sets the expansion of people's political freedom in expression as the basis. But due to the special China's actual condition in the late Qing Dynasty, modern people's political joining was not 
active.

One Hundred Days of Reform was a vital measure for people to join politics, and 1500 successful candidates in the imperial examinations at the provincial level in the Ming and Qing dynasties led by Kang Youwei "submitted a written statement to the higher authority", representing the times main stream. But after 100 days, people's political joining was suppressed, so then people's initiative of joining the politics has decreased obviously. Next, reformers' appearing also aroused people's revolts, so people's political joining gradually expanded, and the revolutionary forces were integrated.

Political modernization failure is the main problem faced by backward countries during development, needing to be solved by efforts from various aspects, such as national unification, public participation, economic development, social resource allocation, etc.

Modernization has large connections in many aspects, and factors closely related to political modernization mainly include the following two: The first one is political mobilization. During that mobilization, values, economic patterns, cultural system in traditional society are eroded continuously, and people gradually accept new political modes and life styles, eager for changes in politics, economy and cultural education; the second one is that with the rising of social productivity, people's social differentiation becomes unavoidable, and people's political joining ability is rising continuously.

During the political modernization of the government in the late Qing Dynasty, due to an inadequate natural endowment and bad postnatal development, there is a dilemma in the modernization process. Economy development made national bourgeoisie seek for more rights through political amelioration, while political system corruption blocked economy development, making national bourgeoisie lack chips in amelioration, also making revolutionaries try to break free from bondage, which all make a thorough revolution inevitable.

At the end of the Qing Dynasty, political amelioration and revolutions were concomitant with each other. Amelioration is a revolution's modern times, while a revolution is amelioration's saltus. The thesis has discriminated amelioration and reforms of the government in the late Qing Dynasty in a horizon of political modernization, providing the following suggestions for modern politics development: The first is elite political normalization; the second is political participation expansion; the third is institutionalization of system operation; the fourth is rationalization of authority foundation. During modernized political transformation, forming a modernization mechanism fit for modern society's development features has prominent value for the overall completion of building socialism with Chinese characteristics.

\section{References}

[1] Shao Huizhuo. On China's Modernization from Perspective of Political Authority [J]. Journal of the Party School of the CPC Hefei Municipal Party Committee, 2016, 22(1): 50-53.

[2] Yang Guang. Analysis of Failure Cause of the Revolution of 1911 in Horizon of Political Modernization [J]. The Fortune Times, 2015, 16(4).

[3] Li Xuezhi. The Revolution of 1911 and Political Change in Modern China: Investigation from Perspective of Modernization [J]. Theory and Modernization, 2012, 17(4): 5-10.

[4] Liu Lina. Study on Historiography that Learning Must be Beneficial for National Affair from Perspective of Political Reform in the Late Qing Dynasty [C]// Review of Political History Study of the Late Qing Dynasty: Problem and Prospect. 2014.

[5] Yang Liangjun. Path Choice of Political Modernization in the Late Qing Dynasty and Its Historical Enlightenment - Constitutional Reform in the Late Qing Dynasty as Example [J]. Open Journal of Historical Studies, 2014, 02(4): 71-78.

[6] Wang Xiaoqiu. Amelioration and Revolution: New Exploration of History in the Late Qing Dynasty and Early Years of the Republic of China [M]. Peking University Press, 2012. 